\title{
Lower toxicity and higher efficacy: a study on a novel fully human anti-EGFR antibody
}

Weiyi Qiu*, Shuang Wang

From 30th Annual Meeting and Associated Programs of the Society for Immunotherapy of Cancer

(SITC 2015)

National Harbor, MD, USA. 4-8 November 2015

We generated a novel fully human anti-EGFR antibody showed lower toxicity and higher efficacy in the preclinical, toxicological and pharmacological studies when compared to a commercial drug Cetuximab. In this research, we aimed to understand the probably mechanism.

Firstly, the $\mathrm{mAb}$ prefers binding to higher expression of EGFR. Its binding avidity on IgG form of the $m A b$ to EGFR was equivalent to Cetuximab, while the Fab affinity was significantly lower. As a result, Higher EGFR expression tissues like tumor obtained the equivalent efficacy as Erbitux, while normal tissues with lower EGFR expression consequently showed lower toxicity.

Secondly, the new mAb had higher concentration in tumor tissue than Erbitux. The accumulation of antibody in tumor local might induce stronger ADCC effect, and resulted in higher anti-tumor efficacy than Erbitux in a Hu-WBC NOD SCID xenograft mice model.

Submit your next manuscript to BioMed Central and take full advantage of:

- Convenient online submission

- Thorough peer review

- No space constraints or color figure charges

- Immediate publication on acceptance

- Inclusion in PubMed, CAS, Scopus and Google Scholar

- Research which is freely available for redistribution
C BioMed Central

(0) 2015 Qiu and Wang This is an Open Access article distributed under the terms of the Creative Commons Attribution License (http:// creativecommons.org/licenses/by/4.0), which permits unrestricted use, distribution, and reproduction in any medium, provided the original work is properly cited. The Creative Commons Public Domain Dedication waiver (http://creativecommons.org/publicdomain/ zero/1.0/) applies to the data made available in this article, unless otherwise stated. 